University of Nebraska - Lincoln

DigitalCommons@University of Nebraska - Lincoln

USDA Forest Service / UNL Faculty Publications U.S. Department of Agriculture: Forest Service -National Agroforestry Center

2012

Forest bioenergy feedstock harvesting effects on water supply

Daniel G. Neary

USDA Forest Service, dneary@fs.fed.us

Karen A. Koestner

USDA Forest Service, kkoestner@fs.fed.us

Follow this and additional works at: https://digitalcommons.unl.edu/usdafsfacpub

Neary, Daniel G. and Koestner, Karen A., "Forest bioenergy feedstock harvesting effects on water supply" (2012). USDA Forest Service / UNL Faculty Publications. 227.

https://digitalcommons.unl.edu/usdafsfacpub/227

This Article is brought to you for free and open access by the U.S. Department of Agriculture: Forest Service -National Agroforestry Center at DigitalCommons@University of Nebraska - Lincoln. It has been accepted for inclusion in USDA Forest Service / UNL Faculty Publications by an authorized administrator of DigitalCommons@University of Nebraska - Lincoln. 


\title{
Forest bioenergy feedstock harvesting effects on water supply
}

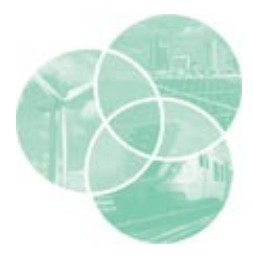

\author{
Daniel G. Neary* and Karen A. Koestner
}

Water flowing from forested catchments, both unmanaged and managed, is highly valued in terms of both quantity and quality. Increasing energy production using wood feedstocks produces varying degrees of impacts and thereby raises concerns about environmental impacts on the highly valued water supply resources of forest ecosystems. The term water supply encompasses both key components of water quantity and water quality. Water quantity considers the amount of increases or decreases, timing, consistency, and relative magnitude of water yields. Plant nutrients (anions and cations), fertilizers, herbicides, ash additions, temperature, dissolved oxygen, $\mathrm{pH}$, bacteria, and sediment comprise water quality. Within the life cycle of forest bioenergy, operational activities during stand establishment, midrotation silviculture, harvesting, product transportation, wood storage, energy production, and ash recycling create variable levels of impacts. Disturbance levels associated with bioenergy operations depend on their type, intensity, frequency, duration, timing, area of extent, and the level of best management practices (BMPs) employed for mitigating of soil disturbances. Feedstock growing, stand tending, harvesting, and wood transportation are considered nonpoint source disturbances since they occur over larger landscapes than energy production activities, which are usually localized at power plants. Water-quantity effects of forest bioenergy production are normally associated with vegetation management and related soil disturbances. Water-quality effects mostly occur as a result of soil disturbances during harvesting, the use of intra-rotation silvicultural chemicals (ash, fertilizers, and herbicides), and inter-rotation site preparation for forest regeneration. Using existing practices designed for environmental protection (BMPs), forest bioenergy programs are completely compatible with maintaining high-quality water supplies in forested catchments. $\odot 2012$ John Wiley \& Sons, Ltd.

How to cite this article:

WIREs Energy Environ 2012, 1: 270-284 doi: 10.1002/wene.26

\section{INTRODUCTION}

Tn 1990, most European countries began the pro1 cess of developing management guidelines and criteria to ensure the conservation and sustainable management of forests. ${ }^{1}$ Criterion Five of the Helsinki Process is to, 'maintain and develop the role of forests in water supply and protection against erosion'. A parallel, but independent, effort was initiated by Canada and joined by other countries with temperate or boreal forests. ${ }^{2}$ Eight out of 67 indicators selected in the Montreal Process and endorsed by the

\footnotetext{
*Correspondence to: dneary@fs.fed.us
}

USDA Forest Service, Rocky Mountain Research Station, Flagstaff, AZ, USA

DOI: $10.1002 /$ wene. 26
10 nations that drafted the Santiago Declaration in 1995 pertain to soil, watershed condition, and the quantity and quality of water resources. Although the Kyoto Protocol of 1997 did not directly address water issues, most countries that were involved in drafting the protocol now recognize that climate change is having a major impact on water supplies worldwide. ${ }^{3}$ Thus, there is considerable sensitivity and concern as to how mitigation responses to climate change, such as the use of forest bioenergy, could potentially affect already stressed water resources.

Wood has always been used by humans as an energy source and once was the chief energy source for much of the world, although used in a dispersed manner. ${ }^{4}$ In the coal, gas, and oil energy period that characterized the twentieth century, its consumption 
for energy production did not reach a large industrial scale until the search for renewable energy resulted in the development of bioenergy programs in the latter three decades. ${ }^{5,6}$ The environmental impact of intensive forestry practices for bioenergy feedstock (woody plant material for combustion and transformation into energy) has been an issue of concern and investigation for many decades because of the growing extent and intensity of forest harvesting and the potential to impact scarce and increasingly valuable water resources. ${ }^{7-13}$ Recent analyses have focused specifically on the potential of forest bioenergy programs to affect water supply. ${ }^{14,15}$ Within the life cycle of forest bioenergy, operational activities during stand establishment, midrotation silviculture, harvesting, product transportation, wood storage, energy production, and ash recycling have the potential to produce disturbances that might affect water resources. There are a number of management practices that are accepted as means of reducing or eliminating the environmental effects of forestry operations and energy production. These are collectively known as best management practices (BMPs). The objective of this paper is to develop a focused analysis of the impacts of forest harvesting on water supply. Although other parts of the forest bioenergy life cycle can affect water resource quantity and quality, harvesting produces the largest changes and is the greatest focus of environmental concern. Bioenergy feedstock production adds some new twists to the forest harvesting story with shortrotation woody crops, slash harvesting, more fertilizer inputs, different plantation age classes, and different evapotranspiration (ET) scenarios. However, most of our understanding of harvesting effects come from past paired catchment studies.

\section{WATER SUPPLY FROM FORESTS}

Forests and woodlands have been relied upon as sources of water since the development of civilizations throughout the world. ${ }^{16}$ Indian, Minoan, Mycenaean, and Egyptian civilizations recognized the need for adequate supplies of good-quality water and the importance of watershed management. ${ }^{17-19} \mathrm{By} 97 \mathrm{AD}$, Rome was a city of over 1 million people with nine aqueducts $400 \mathrm{~km}$ in length bringing in $450 \mathrm{~L}_{\text {person }}{ }^{-1}$ $\mathrm{day}^{-1}$ of fresh water from forested catchments outside the city. The Swiss were leaders in the resurrection of watershed management in Europe after the Dark Ages. Their first watershed protection forests were set aside in 1342 and, by 1777, Switzerland set had aside 322 forests as watershed reserves. ${ }^{20}$ One of the primary objectives of the Forest Reserve Act of
1891 in the United States that created forest reserves that were to become the core of the National Forest System was protection of water supplies.

The reliance on forests for producing sustainable supplies of water is based on two fundamental reasons. ${ }^{21}$ First, forests grow under climate conditions that produce fairly reliable amounts of streamflow. Although streams emanating from forests are affected by drought conditions, they are still more reliable than those originating in other ecosystems. The precipitation needed to sustain forest growth is also adequate to sustain stream base flows or aquifer recharge. This is more true of deep forest soils than shallow soils. ${ }^{22,23}$ Catchment studies in Australia and South Africa have documented greater water yields off of grasslands or forests converted to grasslands ${ }^{24}$ However, these types of catchments often have lesser water quality than forests. Second, forests generally have lower levels of disturbance so they are able to yield higher quality water than agricultural or urban catchments. In the United States alone, over 21,000 public water supplies originate on public and private forest lands. ${ }^{21}$ In addition, there are countless private water supplies that depend on water provided by forest catchments.

Wildfires are the largest threat to forest-based water supplies. ${ }^{25}$ Although water yields after wildfires are usually greater, the quality can be degraded. ${ }^{26,27}$ A number of water supply catchments for major cities in eastern Australia have been affected by wildfires. ${ }^{28}$ The forested Cotter River catchment that is one of two major water supply catchments for Canberra, Australia, was burned by a wildfire in $2003 .{ }^{29} \mathrm{Wa}$ ter quality immediately after the fire was degraded by ash, sediment, and nutrient inputs, but by 2009 water quality recovered to the point where raw water input from the reforested Cotter River catchment was of a higher quality than raw water from the nearby but mainly agricultural Queanbeyan River catchment (see Box 1). Water supply catchments in foothills forests southwest of Denver, Colorado, were adversely affected in a similar manner by wildfires in 1996 and 2002. ${ }^{30}$

Another disturbance that has a potential to affect the water supply function of forests is tree harvesting. ${ }^{14}$ The main disturbance features of forest harvesting are the change in vegetation characteristics that reduces transpiration, and the extraction and transport of biomass materials. Forest bioenergy harvesting is sometimes viewed with more concern because of the intensive nature of the removals. However, forest bioenergy harvesting is no different than intermediate thinning or final stemwood harvests, except for the intensive utilization of slash materials. 


\section{BOX 1: CANBERRA AUSTRALIA WATER}

\section{SUPPLY}

The Australian Capital Territory (ACT) and the City of Canberrra draw water for municipal use from three local catchments. ${ }^{29}$ The first developed (1912) was the Cotter River catchment, which includes part of the unmanaged Namadgi National Park, is mainly native and plantation forest. This system of three dams can store over 86.3 million $\mathrm{m}^{3}$. The second added (1979) was the Googong system (121 million $\mathrm{m}^{3}$ of storage) on the Queanbeyan River in New South Wales that is in a mostly agricultural landscape. The third part of the Canberra system is the Murrumbidgee River which was added as an additional source of water in 2007. The Murrumbidgee River catchment is a mixed forest, urban, agricultural watershed. Water flows by gravity to the Mount Stromolo Water Treatment Plant and then to the ACT distribution system. Daily water use ranges between 108,000 and $124,000 \mathrm{~m}^{3}$ day $^{-1}$. The Cotter River catchment was the primary water supply source because it provided the most pristine water input into the Mount Strombolo Plant even though it was a managed forest. A wildfire in 2003 led to degraded water quality in the Cotter River so the Googong system became the primary supply. By 2009, the reforested Cotter River catchment's water quality had improved to the point where it was less costly to treat the Cotter River supply than the Googong water originating from a mostly agricultural watershed.

Properly managed bioenergy forests are fully capable of achieving the goals of providing sustainable and high-quality water yields for beneficial natural resource, municipal, agricultural, and industrial uses. $^{31}$

\section{HYDROLOGIC CYCLE}

\section{Hydrologic Processes}

The hydrologic cycle quantifies the movement of water from the atmosphere to the land surface and its vegetation, movement within soils and geologic formations, distribution among land and oceanic components of the hydrosphere, and evaporation back into the hydrosphere (Figure 1). Water is a primary driving force in ecosystem physical, biological, and chemical processes and fluxes. The quality and quantity of water in a given ecosystem reflects the net effects of the processes, conditions, and disturbances occurring on component watersheds. Thus the quantity and quality of water emanating from watersheds are indices of ecosystem condition and frequently used as a measure of sustainability. ${ }^{15}$ The hydrologic cycle is discussed in more detail in other publications and is represented by the simple hydrologic equation ${ }^{32}$ :

$$
I=\mathrm{O}+d S,
$$

where $I$ is input, $O$ is output, and $d S$ is change in storage.

A more expanded version of this equation highlights the individual components of input, output, and storage and factors in water supply as an impact on streamflow ${ }^{34}$ :

$$
Q=P-I-T-E-L-W+R-A+d S,
$$

where $Q$ is streamflow, $P$ is precipitation, $I$ is interception, $T$ is transpiration, $E$ is evaporation from soil and plants, $L$ is infiltration into the soil, $W$ is water withdrawals for consumptive use (water supply for multiple uses), $R$ is return flow from water withdrawals, $A$ is aquifer recharge (groundwater in Figure 1 ), and $d S=$ change in storage.

The principal inputs of water that produce streamflow are termed precipitation and consist mainly of rainfall and snowfall. In some coastal regions such as the USA Pacific Northwest, Mexico, and Chile, fog is a major contributor form of precipitation. Water outputs from catchments consist of streamflow, evaporation, and transpiration (often discussed together as evapotranspiration or ET). Water withdrawals for consumptive use consist of water uses for crop irrigation, manufacturing, mining, and municipal water supply. The storage function of the hydrologic equation is composed of surface water detention, soil moisture, and aquifer recharge. Surface water detained in depressions or bodies of water such as lakes or ponds is transient in nature since it eventually is evaporated back into the atmosphere or infiltrates into the soil or geologic formations. Water incorporated into soil profiles has a range of residence times depending on its storage in quickly draining macropores, recalcitrant micropores, or clay mineral interstices. Long-term storage of water in unconsolidated or consolidated geologic formations known as aquifers can occur over periods of a few to millions of years. Water moving into aquifers can originate directly from soil infiltration or channel inflow into unconsolidated sediments or porous rocks. In many locations water supply comes from aquifers and not surface streamflow. Where ET is high due to aridity, latitude, altitude, clear air, and wind, streamflow is minimal, episodic, or nonexistent. In most ecosystems with precipitation $<480 \mathrm{~mm}$, streamflow occurs only after large storm events, during periods of the year like winter when ET is low, and as a result of snow melt. ${ }^{35}$ Water can be temporarily stored for both short and long periods of time in both organic and mineral 


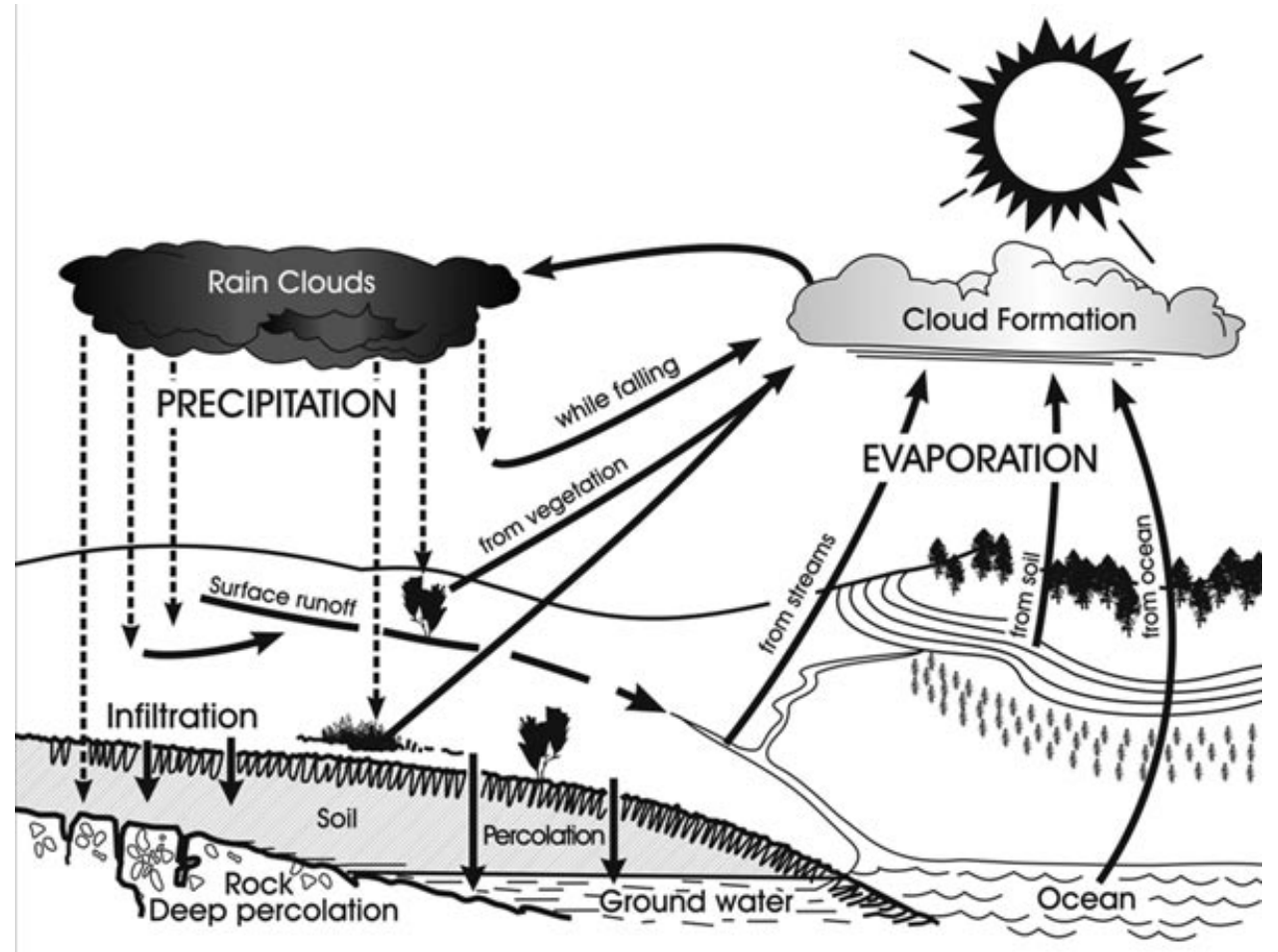

FIGURE 1 | Components of the hydrologic cycle. ${ }^{33}$

horizons of the soil, weathered bedrock directly beneath the soil, in porous bedrock formations, and in unconsolidated alluviual and channel sediments. ${ }^{36}$ Water withdrawals are the supply function of the expanded hydrologic equation. Part of the water supply removed for consumptive use is lost back to the atmosphere as ET, and some returns to the streamflow component as return flow from irrigation usage and wastewater treatment.

A generalized breakdown of the inputs, fluxes, and outputs in undisturbed forested watersheds in humid regions is shown in Figure 2. ${ }^{15}$ These percentage breakdown of water movement changes somewhat in arid shrub, grassland, and woodland ecosystems, and can vary considerably in watersheds disturbed by climate change, harvesting, burning, insect defoliation, windthrow, land-use conversions, mining, and agriculture. Precipitation inputs consist of rain, snow, sleet, and so on $(100 \%)$. In undisturbed or wellfunctioning watersheds, the movement pathways for water are dominated by ET and infiltration. These processes produce the baseflow (streamflow between storm events) that exits the catchment area on a time frame of weeks to years and provides for a good water supply (Figure 2, right side). Management activities or disturbances that shift water fluxes to the left of Figure 2, toward surface runoff, ultimately de- grade the value and usefulness of the water resource. ${ }^{37}$

Plant leaf, branch, stem, and woody debris surfaces intercept precipitation, causing most of it to be evaporated back into the atmosphere. This process catches and retains $7 \%$ of the initial precipitation from a storm event, depending on the degree of surface cover. Small, low-intensity storms have higher amounts of interception than larger, highintensity and windier events. The reduction of intercepting surfaces after harvesting increases the amount of rainfall reaching the forest floor or mineral soil surface. Other amounts of intercepted rainfall flow down plant stems, logging slash into the soil as stemflow or are lost back to the atmosphere as evaporation. Snow hung up in a forest canopy eventually falls through to the forest floor or is directly evaporated back into the atmosphere through sublimation (water phase change from solid to gas without the intermediate liquid state. ${ }^{32}$

Precipitation that penetrates through a forest canopy and lands on litter, slash, or bare soil is called throughfall. In undisturbed forests, about $91 \%$ of precipitation infiltrates directly into the litter and mineral soil (infiltration), with only $1 \%$ flowing over the soil surface as surface runoff (Figure 2). When rainfall intensity exceeds infiltration capacity, surface 


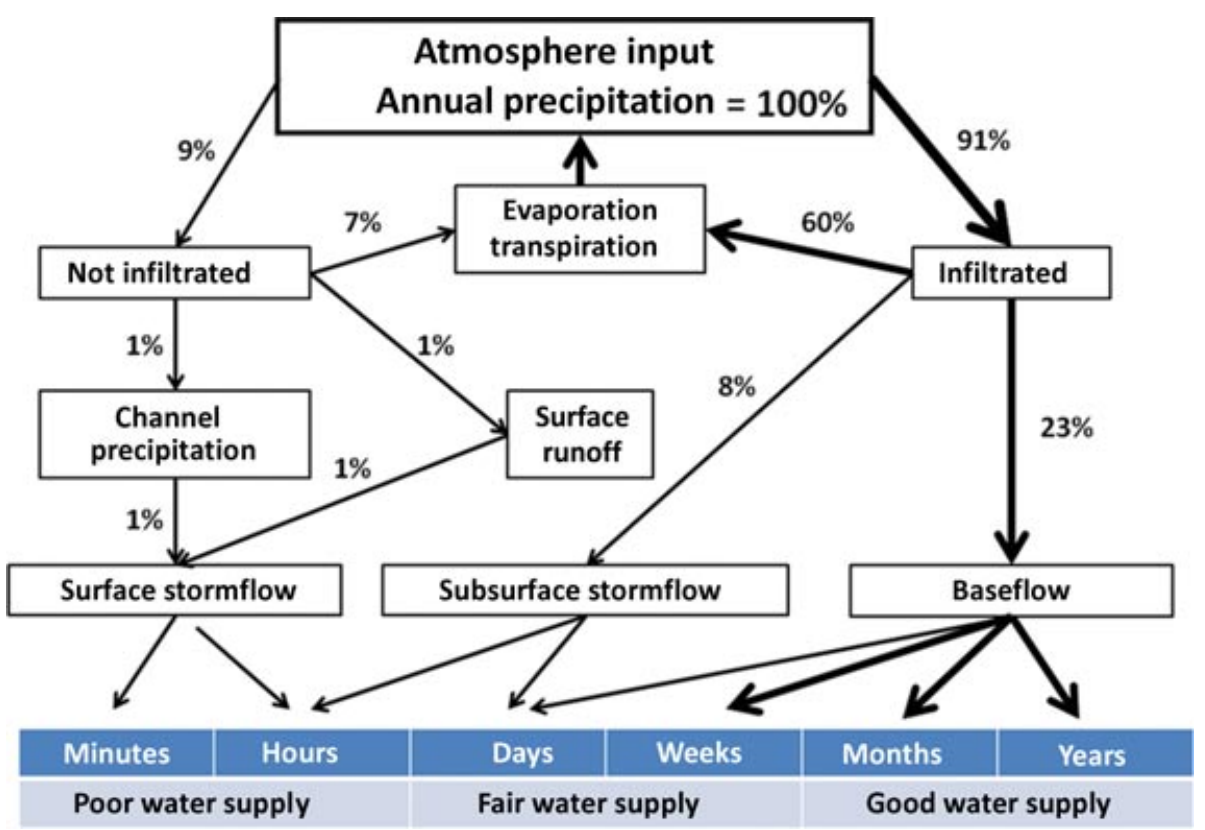

FIG URE 2 | Partitioning of precipitation into output components in undisturbed forest catchments in humid regions and the effect on water supply. (Reprinted with permission from Ref 35. Copyright 2002, Elsevier.)

runoff occurs. Litter cover, soil texture, vegetation, and soil porosity affect infiltration rates. With litter present as a cover on mineral soil in forests, hydraulic conductivities $^{38}$ often exceed peak rainfall intensities $\left(>160 \mathrm{~mm} \mathrm{~h}^{-1}\right)$. Infiltrating rainfall moves laterally and vertically in the soil as interflow. The movement can be fast in large pore spaces in the soil (macropores) or slow in small pores (micropores).

Interflow results in temporary storage of water and ultimately produces the baseflow that is the source of the perennial flow of streams. Streamflow consists of baseflow between and during storm events and stormflow only during and immediately after rainfall. Baseflows are the consistent flows characteristic of forested watersheds that provide sustainable water supplies. Stormflows are much higher than baseflows because they are produced by processes such as in-channel precipitation and surface runoff that are minimally affected by evaporation, transpiration, and soil moisture storage capacity. The stormflow component of water yield is highest in semiarid environments and the least in higher rainfall climates. The magnitude and duration of stormflow is a function of climate characteristics, as well as the watershed condition after harvesting. As the period of record for watersheds increases, the probability of observing stormflows outside their known 'range of natural variability' logically increases due to the chance occurrence of extreme climatic events. Evidence is accumulating that climate change is produc- ing more weather events outside the previously understood 'range of natural variability'. ${ }^{3}$ The response of forested catchments to these unusual events is a function of precipitation characteristics (amount, intensity, and duration), season, topography, vegetation cover, litter, soils, and geology. Forest harvesting may have a significant effect on stormflows or none at all.

Forest harvesting per se does not affect the magnitude of the flow pathways shown in Figure 2. Cutting trees shifts some of the flow from ET to baseflow. However, high levels of soil disturbance (e.g. physical exposure, removal, or tilling, and development of chemical water repellency) can shift more water originating from precipitation to the "water not infiltrated' side of the flow diagram. The result is higher overland flows and surface stormflows that produce damaging peakflows or floods. A concomitant impact of increased surface stormflows is a reduction in long-term soil moisture and baseflows. Soil moisture is critical for regenerating vegetation, and baseflows are important for maintaining aquatic habitat and water supplies.

Watershed (catchment) condition is a more logical term that describes the ability of a watershed system to receive, route, store, and transport precipitation. With good conditions, rainfall infiltrates into the soil, and baseflows are sustained between storms. In this situation, rainfall does not contribute to increased surface runoff and water quality degradation since most of the precipitation does not flow 
TAB LE 1 | General Effects of Forest Harvesting on Specific Hydrologic Processes ${ }^{15}$

\begin{tabular}{|c|c|c|}
\hline Hydrologic Process & Type of Change & Specific Effect \\
\hline 1. Interception & Reduced & $\begin{array}{l}\text { Moisture storage smaller; greater runoff in } \\
\text { small storms; increased water yield }\end{array}$ \\
\hline 2. Throughfall & Increased & Baseflow increased; soil moisture increased \\
\hline 3. Evaporation & Increased & Baseflow decreased; soil moisture decreased \\
\hline & Decreased & Baseflow increased; soil moisture increased \\
\hline 4. Litter storage & Litter reduced & Less water stored $\left(0.5 \mathrm{~mm} \mathrm{~cm}^{-1}\right)$ \\
\hline & Litter not affected & No change \\
\hline & Litter increased & Storage increased \\
\hline 5. Transpiration & Temporary elimination & Baseflow increased; soil moisture increased \\
\hline 6. Infiltration & Reduced & $\begin{array}{l}\text { Overland flow increased; stormflow } \\
\text { increased }\end{array}$ \\
\hline & Increased & Overland flow decreased; baseflow increased \\
\hline 7. Streamflow & Changed & $\begin{array}{l}\text { Increase in most ecosystems; decrease in } \\
\text { snow systems; decrease with type } \\
\text { conversion } \\
\text { Decrease in fog-drip systems }\end{array}$ \\
\hline 8. Baseflow & Changed & $\begin{array}{l}\text { Decrease with less infiltration; increase with } \\
\text { less transpiration; summer low flows (+ } \\
\text { and-) }\end{array}$ \\
\hline 9. Stormflow & Increased & $\begin{array}{l}\text { Greater volume; larger peakflows; time to } \\
\text { peakflow shorter }\end{array}$ \\
\hline 10. Snowpack & Charged & $\begin{array}{l}\text { Cuts }<4 \text { ha, increase snowpack cuts }>4 \text { ha, } \\
\text { decrease in snowpack; snowmelt rate } \\
\text { increased; evaporation/sublimation } \\
\text { greater }\end{array}$ \\
\hline
\end{tabular}

over the surface where it can detach and transport sediments (Figure 2). Severe fires, poor harvesting practices, overgrazing, conversion to agriculture, mining, and urban uses degrade watershed condition, causing the percentage of infiltrated rainfall to be reduced significantly. Rainfall then runs over the soil surface, resulting in little or no baseflow between storms (Figure 2), and erosion is accelerated during storm runoff events. The result is a watershed whose water supply value is poor. The surface conditions that promote good watershed condition include: (1) the presence of a surface organic horizon (O horizon) $<5 \mathrm{~mm}$ to $>20 \mathrm{~cm}$ thick; (2) herbaceous, shrub, and woody vegetation (variable cover); and (3) welldeveloped and intact soil horizons with high surface roughness. For the most part, forest bioenergy systems are able to provide these conditions.

\section{Harvesting Effects}

Forest harvesting and associated site preparation activities are the largest management disturbances in the life cycle of a forest from which fire has been excluded. They affect processes in the hydrologic cycle that determine the sustainability and quality of water supply. The specific hydrologic effects depend upon intensity, frequency, duration, timing, cutting area of the harvest; the type of harvesting equipment and extraction systems used; and the level of BMPs employed for mitigation of soil disturbances. Water quantity changes are determined by the degree and patterns of overstory and understory canopy removal while water quality changes are mostly the result of forest biomass reduction and the degree of soil disturbances. Changes in baseflow, streamflow, and stormflow definitely affect both the quantity and quality of water delivered from forested catchments (Table 1). The following discussion is a general summary of the effects of forest harvesting in a bioenergy setting, not a site-specific analysis. The occurrence and magnitude of these effects is a function of the general climate, precipitation, aspect, latitude, severity of disturbance, and the percentage of a catchment harvested.

\section{MEASURED WATER QUANTITY CHANGES}

Water quantity increases due to forest harvesting for bioenergy or other products as well as intermediate 


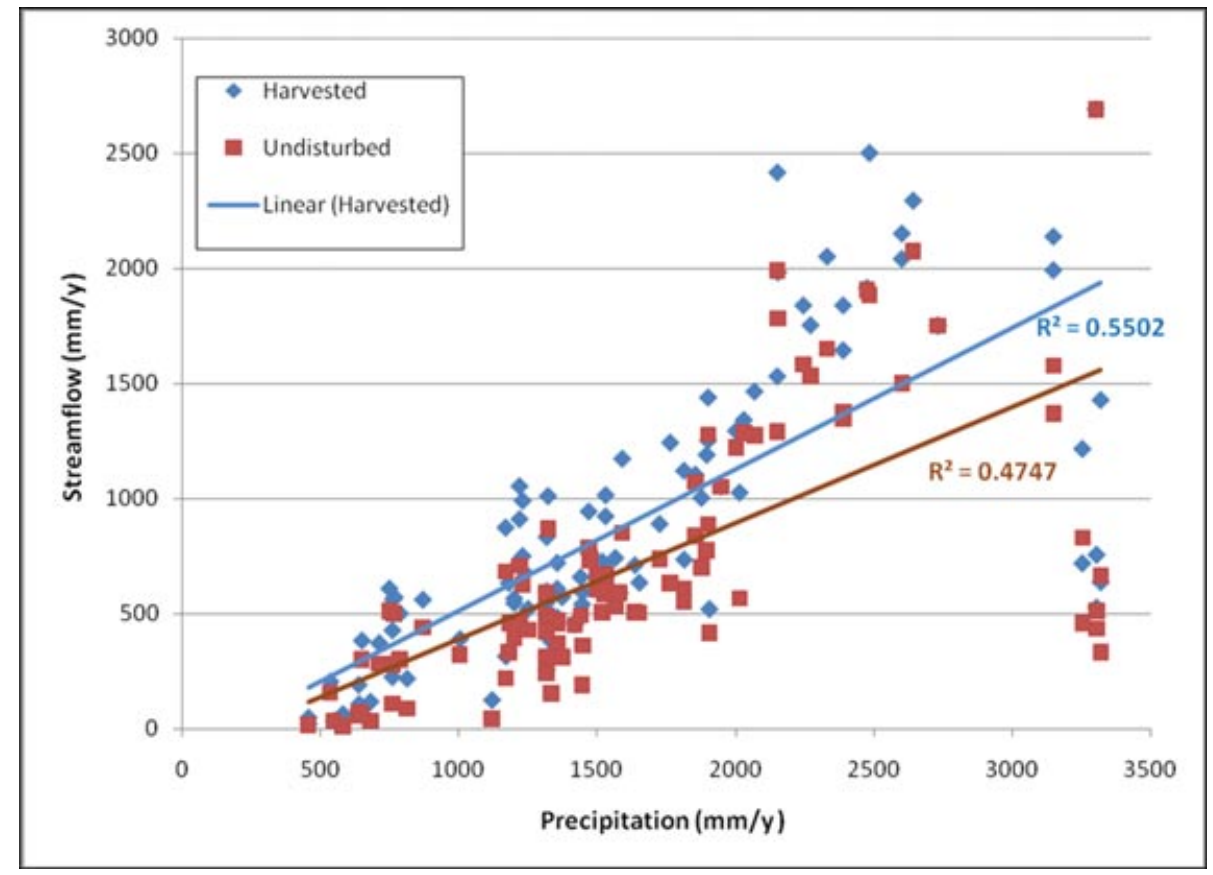

FIGURE 3 | Effect of precipitation on streamflow in undisturbed and harvested forest ecosystems..$^{9,10,14,15}$

thinning are very ecosystem specific. The flow of water from forested catchments is usually greatest after the first year following tree cutting. ${ }^{32}$ Thereafter, the increased quantity of water yield associated with tree cutting or vegetation control declines as vegetation recovers and leaf area index returns to preharvesting conditions. This recovery period has been measured to be as short as 1-4 years in forests with high growth rates (e.g. Eucalyptus spp. in Brazil), high ET rates $^{11,12}$ and low precipitation, and over 10 years in ecosystems with high rainfall and low ET. ${ }^{10,22} \mathrm{Wa}$ ter quantity increases of $80-100+\%$ have been measured in high precipitation regions $(1500-2600 \mathrm{~mm}$ year $^{-1}$ ) to $<20 \%$ in low precipitation areas $(450$ $600 \mathrm{~mm}$ year $\left.^{-1}\right)$. In some long-rotation native forest regeneration systems, harvesting results in an initial water yield increase followed by declines that have been reported to last up to 100 years. ${ }^{39}$ There are a number of site and climate factors, which affect the hydrologic equation and determine the degree of catchment response measured in numerous studies around the world.

\section{Annual Yield Increases}

The largest effect of forest harvesting for bioenergy feedstocks is to immediately increase the water yield (Figure 3). The only situation where this statement is not true is in coastal forests that derive much of their precipitation input from fog drip. The amount of water yield increase after forest harvesting is a function of the proportion of a watershed that is cut, the amount of precipitation, and site factors such as aspect, soils, and vegetation. Aspect, which is a good local indicator of relative potential ET, has a strong influence on water quantity responses to forest harvesting. Slopes oriented normal to solar radiation receive the highest loadings and therefore have the highest ET. In general, mean annual streamflow increases as the percentage harvest of a forest stand or watershed increases and precipitation increases (Figure 3). Streamflow is usually minimal at the low end of the precipitation range for forest ecosystems $\left(450-1000 \mathrm{~mm} \mathrm{year}^{-1}\right)$ and increases due to forest harvesting are often undetectable. Evaporation is such a powerful factor in low precipitation climates, that basin-wide vegetation management or species conversion does not have much effect on streamflow. ${ }^{32}$ Water quantity increases can be substantial (200$760 \mathrm{~mm} \mathrm{year}^{-1}$ ) in forests that occur in high precipitation zones, but some anomalies exist (e.g., rainforests).

A considerable amount of research has been conducted in the past on the hydrologic effects of forest harvesting on over $105+$ individual catchments. The results have been summarized in a number of syntheses. ${ }^{9,14,15,40}$ These studies have been very costly to install and monitor, and have required considerable dedication to their continuity by hydrologic scientists. The earliest watershed experiments were 


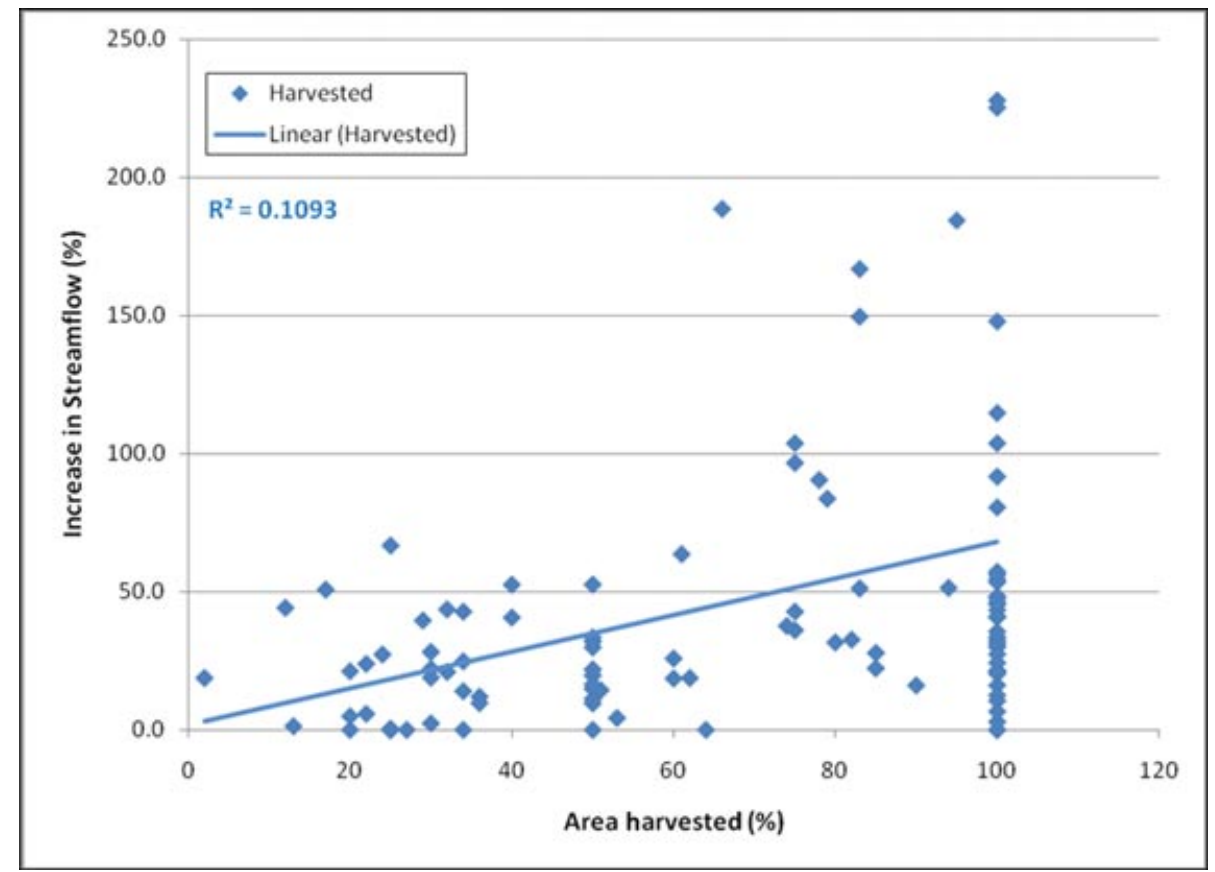

FIG URE 4 | Relationship between forest area harvested and streamflow increase. ${ }^{9,10,14,15}$

installed in Switzerland, Japan, and the United States in the first ten years of the twentieth century. ${ }^{16}$ Some have been in existence since the 1930s. Researchers have examined various harvesting intensities, configurations, and timing.

With a $100 \%$ clearcut harvest, first-year water yield increases reported in the literature generally range from $0 \%$ to $225 \%$ (Figure 4 ). The absolute amount of water yield is strongly related to a number of factors such as the annual rainfall, vegetation type, ET regime, aspect, leaf area reduction, and soil depth. $^{22,32,39-41}$ Although the absolute water yields increase the first year after harvesting and increase with total precipitation, the percentage increase is poorly correlated to precipitation amount (Figure 4). Indeed, the greatest variation occurs at $100 \%$ harvest because other factors in Eq. (2) override transpiration reduction. Vegetation type is strongly correlated to streamflow increases after forest harvesting (Figure 5). Broadleaved forests have the highest mean increase in water quantity after harvesting $(237 \mathrm{~mm})$ compared to coniferous forests $(161 \mathrm{~mm})$ or mixed conifer-broadleaved forests $(170 \mathrm{~mm})$. They also produce the most predictable responses.

Harvesting of forests has been used to augment municipal water supplies because of the resulting increases in water yield. ${ }^{10,32}$ The duration of the response depends on a number of factors. Generally, the increase in total water yield after harvesting is considered to be a benefit, and not of sufficient mag- nitude to produce adverse hydrologic or ecosystem effects (e.g., flooding). However, vigorously growing young forest stands can cause subsequent water yield declines. Short-rotation Eucalyptus spp. plantations are an example. ${ }^{11,24,42}$ In a landscape managed for forest bioenergy landscape, the increases due to harvesting could offset the declines, but this is a topic for further investigation.

\section{Annual Yield Decreases}

Water yield declines after reforestation or conversion of native forests or agriculture to coniferous forests have been addressed by a number of researchers. $^{7,23,43-45}$ Water quantity increases decline to baseline levels over a period of 7 to 25 years depending on ecosystem, climate, and tree species. That may be followed by a period of three to ten decades where water yields fall below baseline levels. ${ }^{39,46}$ This is especially the case where broadleaved trees are converted to coniferous forests, altering ET dynamics. Declines in annual flows from pretreatment conditions are typically due to increases in interception, transpiration, and evaporation [see Eq. (2)].

A case of water quantity decline after forest harvesting was documented in coastal conifers in Oregon that scavenged water from fog. ${ }^{47}$ Removal of the forest cover drastically reduced oceanic fog interception, which was a major component of precipitation input, and thus produced a decline in annual 


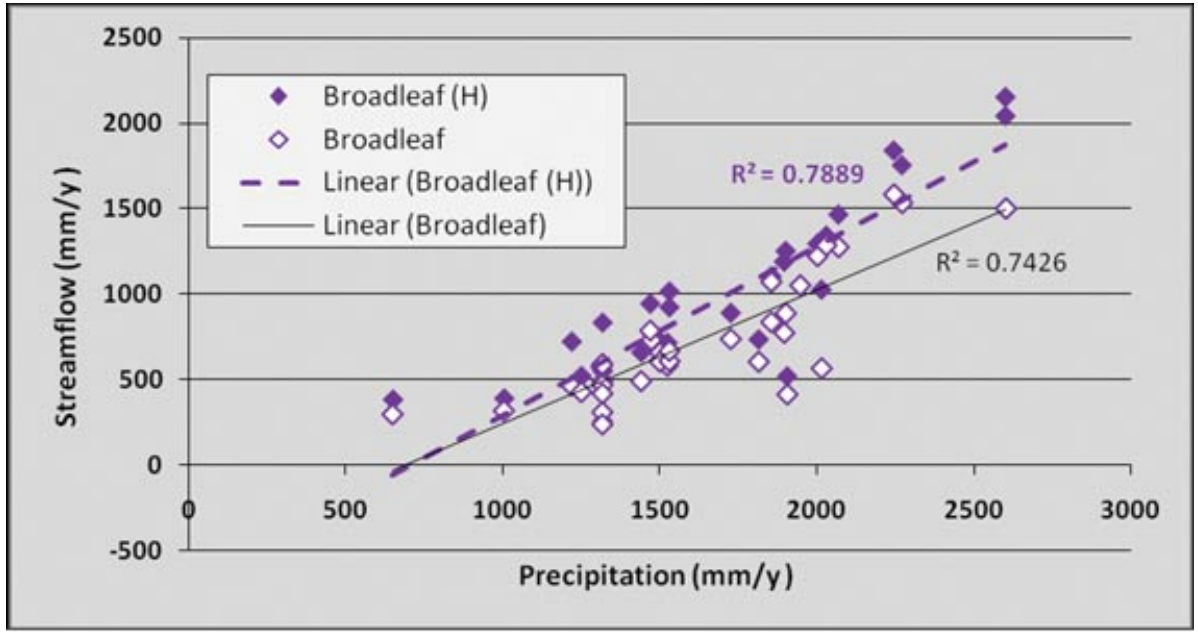

(a)

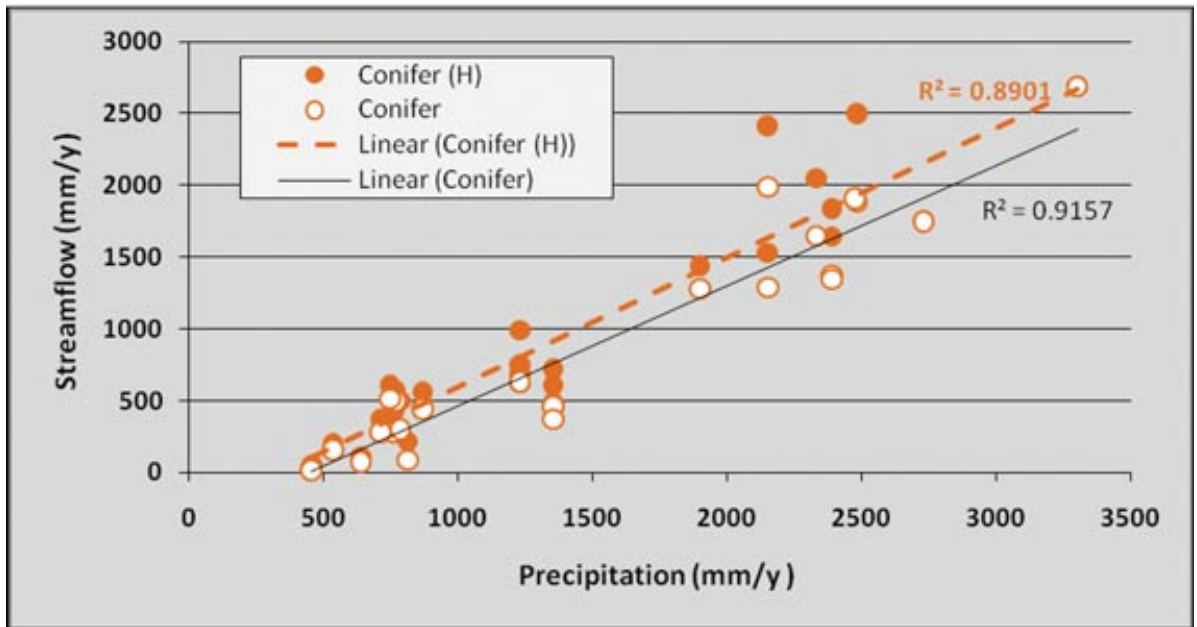

(b)

FIG URE 5 | Relationship between precipitation and undisturbed and harvested forests (H): (a) broadleaved forests, and (b) conifer forests. ${ }^{9,10,14,15}$

water yields. In most cases, water quantity declines after forest harvesting are the result of type conversions or reversions such as agriculture to forest ${ }^{48}$ or grassland to Pinus spp. or Eucalyptus spp. ${ }^{42}$ This is an area requiring additional research to determine the cumulative effect on a landscape basis and for large water supply catchments. Factors causing water yield declines below base levels after harvesting are discussed elsewhere. ${ }^{39}$ There is a scale factor in that effects observed at a small catchment scale may not hold up when analyzed at the larger landscape level. ${ }^{8}$ Reforestation to the same tree species typical in a bioenergy forest management scheme is not likely to produce declines in the annual output of streamflow. Year-to-year climatic variation and aspect effects are constant sources of water yield increases and decreases.
The H.J. Andrews Experimental Forest is situated in the western Cascade Range of Oregon in a 6400 ha catchment of Lookout Creek, a tributary of Blue River and the McKenzie River. ${ }^{49}$ It is representative of the rugged mountainous landscape of the United States's Pacific Northwest and it contains conifer species typical of many Cascade Range forests of the region. Lower elevation forests are dominated by Douglas-fir (Pseudotsuga menziesii), western hemlock (Tsuga heterophylla), and western redcedar (Thuja plicata). Upper elevation forests contain noble fir (Abies procera), Pacific silver fir (Abies amabilis), Douglas-fir, and western hemlock. The northwest-facing Watershed 1, 96 ha in size, was $100 \%$ harvested in $1962 .{ }^{49}$ It produced a first-year increased total annual water yield of $462 \mathrm{~mm}$ that declined progressively to $330 \mathrm{~mm}$ five years later. The 


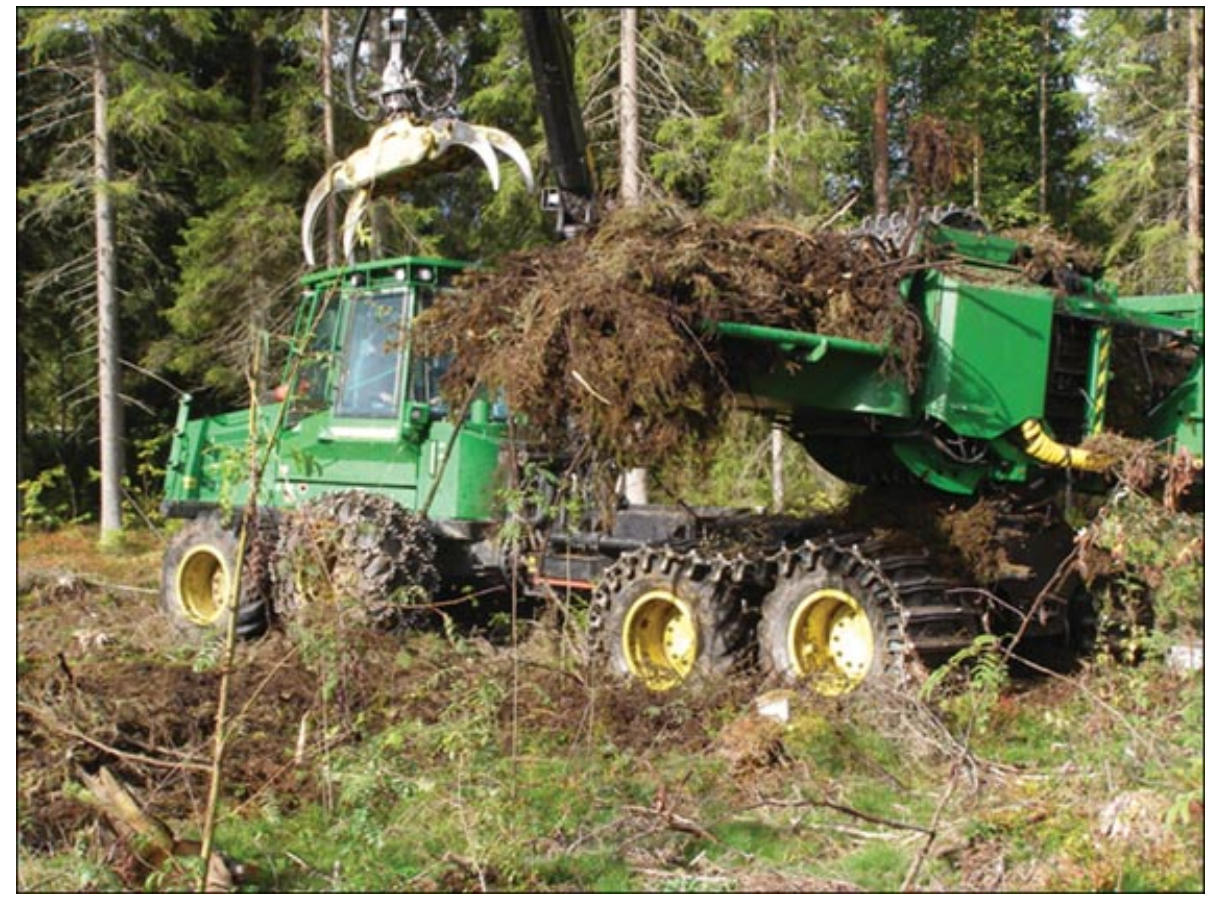

FIG URE 6 | Harvesting of slash materials in Finland using a low ground pressure and tracked Deere bundling system (photo by Daniel G. Neary).

south-facing Watershed 6, 13 ha in area, was also $100 \%$ clear felled 12 years later in 1974 and it produced a first-year total annual yield increase of $425 \mathrm{~mm}$ that declined to $180 \mathrm{~mm}$ by year five. ${ }^{41}$ Another south-facing catchment, Watershed 10 with an area of 9 ha, produced a first-year flow increase of $195 \mathrm{~mm}$. However, water yields increased the next two years to 310 and $400 \mathrm{~mm}$. The fourth year they dropped to $65 \mathrm{~mm}$. The precipitation variations over those years demonstrated that water quantity changes after forest harvesting can be highly variable, particularly in forest ecosystems that are warming and drying.

\section{Peakflows}

A more important parameter of concern is flood peak flows. It has been known for centuries that forested lands are less prone to high peakflows than those converted to agricultural purposes. Study of the literature indicates that harvesting forests produces a mixed peakflow response. ${ }^{7,15}$ Where snowmelt runoff is an important component of annual hydrographs, declines in peakflows up to $35 \%$ have been reported after forest harvesting. ${ }^{50,51}$ Some investigators have reported no peakflow response to harvesting. ${ }^{44,52}$ In other locations, watershed, vegetation, and climatic characteristics have produced peakflow increases of up to $1400 \%$. However, such large-magnitude responses are rare, and more often produced by con- comitant disturbances like wildfire. Several investigators have concluded that except for unusual storm events, harvesting and reforestation do not result in significant increases in peakflows. ${ }^{15,46,48}$ Some combinations of terrain, geology, soils, vegetation, and climate may combine to create localized hazards. ${ }^{14,15}$

\section{MEASURED WATER QUALITY CHANGES}

Because of the recognition of forests as being major sources of water supply, a considerable number of research studies have investigated the impacts of forest harvesting on water quality in the past 50 years. The water quality parameters commonly examined by these studies are nitrate-nitrogen $\left(\mathrm{NO}_{3}-\mathrm{N}\right)$, ammonia nitrogen $\left(\mathrm{NH}_{4}-\mathrm{N}\right)$, phosphorus $(\mathrm{P})$, major cations (sodium, $\mathrm{Na}$; potassium, $\mathrm{K}$; calcium, $\mathrm{Ca}$; and magnesium, $\mathrm{Mg}$ ), sediment, temperature, $\mathrm{pH}$, and microorganisms. These parameters are important for streams being used as water supplies, and for their potential impact on aquatic biota, particularly threatened and endangered species. Heavy metals are a water quality concern in association with mining activities and some biosolids or waste reuse, and are not normally associated with forest bioenergy harvesting. Syntheses of the water quality studies relating to forest harvesting have been provided by several investigators. ${ }^{9}, 14,15,40$ 


\section{Nutrients}

Nitrate-nitrogen is often used as an indicator of watershed health and good quality water. It is a good integrator of watershed processes and an indicator of disturbance. ${ }^{13}$ It is used throughout the world as a key water quality standard for human health. Large increases in $\mathrm{NO}_{3}-\mathrm{N}$ levels in streams draining harvested catchments have not been measured except where herbicides have been used to suppress postharvesting vegetation regrowth, ${ }^{15,50}$ or nitrogen saturation of ecosystems has reached a critical level due to atmospheric deposition. ${ }^{53}$ There is no indication in the scientific literature that water quality standards (10 $\mathrm{mg} \mathrm{L}^{-1} \mathrm{NO}_{3}-\mathrm{N}$ ) are threatened by postharvesting $\mathrm{NO}_{3}-\mathrm{N}$ increases since most measured increases are $<0.5 \mathrm{mg} \mathrm{L}^{-1} \mathrm{NO}_{3}-\mathrm{N}$.

Increases of other nutrients after forest harvesting have been examined by many investigators and summarized by major syntheses. ${ }^{9,14,15,54}$ Although the conservative nutrient cycles of undisturbed forests are temporarily interrupted by harvesting, the shortterm nature of harvesting disturbances and usually vigorous regrowth of vegetation limit water quality impact. Several scientists ${ }^{14,54}$ have concluded that there is no evidence of forest harvesting producing a significant adverse impact on the quality of water supplies from additional dissolved inorganic ions in streamflow.

\section{Sediment}

Sediment is an important water quality parameter for water supplies as it can harm aquatic organisms and habitats, render water unacceptable for drinking water supplies or recreation purposes, or result in large expenditures by municipal water treatment facilities to bring input waters up to standards. Although increased sediment movement into streams is a major environmental concern in managed forest catchments, it also occurs naturally without human-associated disturbances. Watersheds vary greatly in their natural sediment load characteristics ranging from $<0.01$ to $140 \mathrm{Mg} \mathrm{ha}^{-1}$ year $^{-1}$ depending on climate, geology, and soils. ${ }^{14}$ Sediment deposits can be re-entrained after initial deposition in ephemeral or perennial stream channels, and move downstream with streamflow for long time periods and distances. The cumulative effects of erosion and sedimentation that occurred centuries ago from agriculture, mining, urbanization, or forestry present watershed managers with many current challenges.

Sediment yield increases and water turbidity produced by forest harvesting are the largest and most visible water quality impacts on water supply. ${ }^{15}$ The degree to which sediment impairs the quality of wa-
BOX 2: BEST MANAGEMENT PRACTICES IN AUSTRALIA PROTECT WATER QUALITY

In Australia, natural resource managers are striving to enhance environmental outcomes at farm and catchment scales by planting streamside management zones (SMZs) with trees to produce a variety of ecological services including bioenergy feedstocks. A study was conducted in Tasmania, Australia, to evaluate the water quality benefits of an SMZ and the effects of tree harvesting. ${ }^{55}$ This case study consisted of a 20-year-old Eucalyptus nitens pulpwood/bioenergy feedstock plantation in an SMZ of an intermittent stream that was harvested according to Code of Forest Practice of the state. A machinery exclusion zone adjacent to the stream limited machinery traffic. Tree harvesting in the Tasmanian study resulted in minimal mineral soil exposure $(<11 \%)$ and increased surface roughness. Postharvesting turbidity levels in streamflow were similar to preharvest levels and an unharvested reference catchment $[<2.5$ nephelometric turbidity units (NTUs)] in streamflow exiting the harvested catchment. Much more significant sources of sediment were a road, a stream section that was accessible to cattle, and a cultivated paddock. These sources led to turbidities of about 300 NTUs in a dam immediately below these points and above the harvested stream reach during a postharvest storm. In-stream dams, installed many years earlier to store water for stock and irrigation, also acted as very effective sediment traps. The SMZs and other BMPs used in the agroforestry landscape were effective at protecting water quality. Forest harvesting for bioenergy feedstocks can be conducted in SMZs without increasing stream turbidity, if existing BMPs and the appropriate harvesting equipment are used.

ter supplies after forest harvesting is highly variable and depends on such factors as soils, climate, topography, ground cover, watershed condition, the type of harvesting equipment used, and the transportation system. Physical disturbance of soil followed by high rainfall intensity or amounts is the main reason for sediment yield and turbidity increases after harvesting, but they are usually transient due to understory vegetation recovery. Soil disturbance and sediment movement can be significantly reduced by use of low ground pressure and wide-tracked harvesters (Figures 6 and 7). Recent research has documented the success of BMPs in limiting postharvest water quality declines. $^{27}$ (see Box 2). ${ }^{55}$

The major sediment problems documented in the literature have been associated with $\log$ extraction methods, ${ }^{55}$ postharvest 


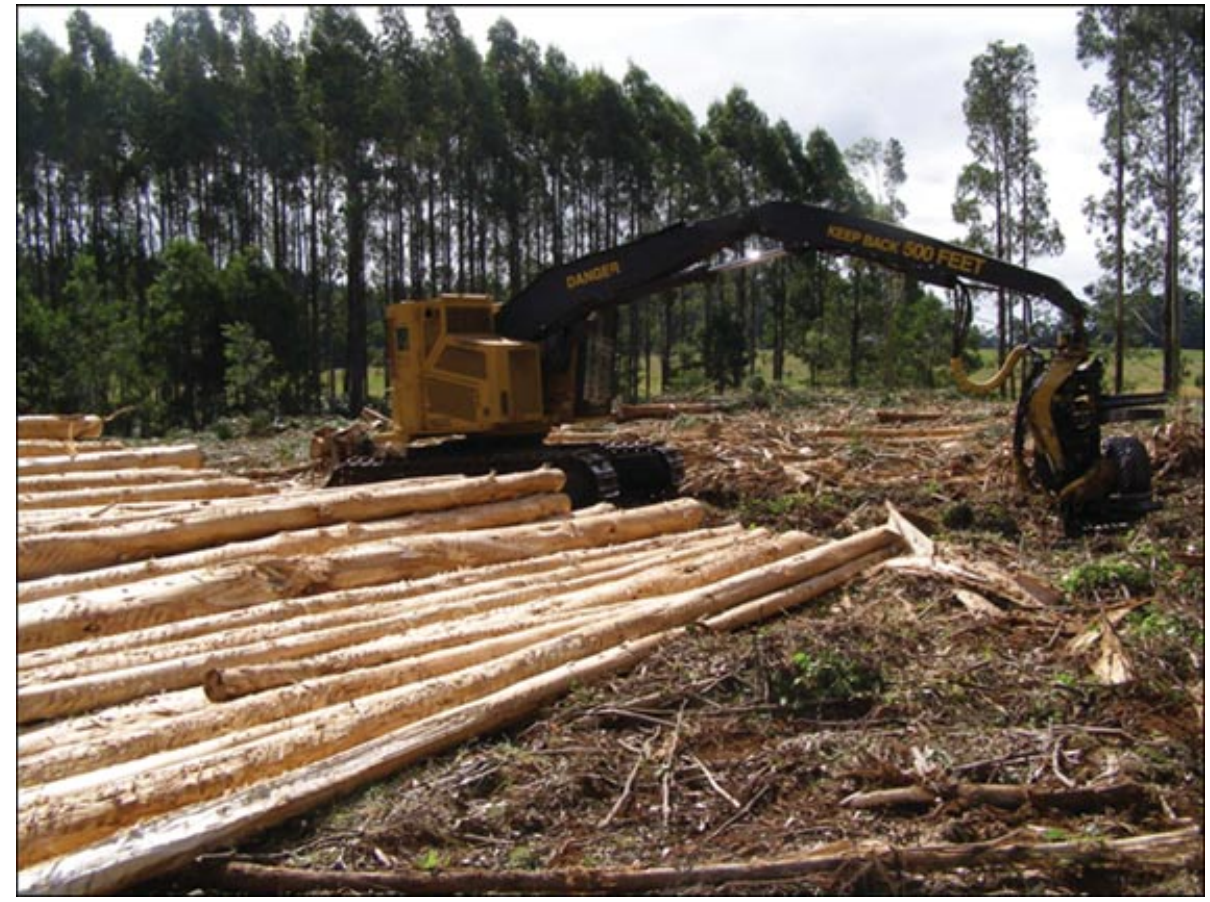

FIG URE 7 | Stacking of a Eucalyptus nitens stems in a SMZ in northern Tasmania, Australia, by a Tigercat tracked harvester (photo by Daniel G. Neary).

mechanical site preparation, ${ }^{56}$ slope instability, ${ }^{57}$ road construction, ${ }^{58}$ or highly erosive soils. ${ }^{14}$ BMPs are effective in reducing on-site sediment movement when they are properly planned and implemented prior to, during, and after harvesting. Most BMPs relate to designing, constructing, and maintaining major access roads, logging roads, skid trails, and landings. These areas are the primary sources for $90 \%$ of the sediment generated by harvesting. ${ }^{59}$ The underlying principles of BMPs are aimed at minimizing disturbances in streamside zones, reducing the erosive power of runoff on bare soils and road surfaces, and maintaining the normally high infiltration capacity of forest soils.

\section{Temperature}

Forest vegetation maintains stream temperatures that are cooler and less variable than unshaded stream reaches by blocking solar radiation. ${ }^{14,15}$ Increases in temperature that result from forest harvesting affect physical, chemical, and biological processes. The impact on aquatic biota varies considerably, depending on whether or not individual species are adapted to wide temperature ranges, and the degree to which stream temperature is controlled by solar heating or stream baseflow. A more complete discussion of temperature impacts is summarized elsewhere. ${ }^{14,32}$ Unacceptable increases in stream temperature can be miti- gated by using buffer strips as a BMP. The cumulative effects of stream temperature increases are often moderated as streamflow from harvested areas with higher temperatures merge with those from larger, uncut areas.

\section{CONCLUSION}

\section{Water Quantity}

There is a large body of science across the world on the water yield effects of forest harvesting $(>105$ individually studied watersheds). The overwhelming majority of these were studies of traditional forest harvesting. In many locations, silviculture operations in bioenergy forests do not differ substantially from traditional fiber- and timber-producing ones. Forest harvesting to provide feedstocks for bioenergy developments is not likely to adversely affect the quantity of water supplies. In most instances, water yields increase after harvesting and then return to baseline levels 7-25 years later, depending on climate and forest ecosystem. Declines in water yield have been measured only in special instances such as fog-drip forests, type conversions from grasslands or agriculture to coniferous forests, and restoration of riparian and plantation forests in landscapes converted to grasslands. ${ }^{24}$ Peakflows are probably the biggest concern relative to forest harvesting. Research has shown 
increases, decreases, and no change in peakflows after harvesting. The consensus of scientific opinion is that, except for unusual storm events, harvesting, and reforestation do not result in significant increases in peakflows. Future research needs to concentrate on analyzing water balances across large catchments that include a range of harvest units spanning entire rotations, water supply reservoirs, agricultural areas, and urban settings to determine the large-scale impact of forest harvesting for bioenergy feedstocks. Paired catchment research is also needed to evaluate the water yield effects of intensive short-rotation plantation forests. In most instances, there are sufficient BMPs available to mitigate potentially adverse impacts.

\section{Water Quality}

Several syntheses have concluded that there is no evidence of forest harvesting producing a significant, long-term adverse impact on the quality of water supplies from dissolved inorganic ions in streamflow such as nitrates, phosphates, and cations. Short-term in- creases do occur in forest catchments, but with normal harvesting and reforestation operations there is no long-term effect. Forest affected by large-scale disturbances such as wildfire and salvage logging usually recover quickly and produce higher quality water than catchments where agriculture is the dominant land use. Sediment is the main water quality problem associated with forest harvesting operations. The main sources of water quality deterioration are associated with log extraction methods, postharvest mechanical site preparation, slope instability, road construction, or highly erosive soils. Water temperature can be a concern where cold-water fisheries are important resources. BMPs are often effective in reducing sediment movement and water temperature changes when they are properly planned and implemented prior to, during, and after harvesting. Future research relative to forest bioenergy harvesting should concentrate on the cumulative effects of changes in the physical, chemical, and biological quality of water in intensively managed short-rotation plantations.

\section{REFERENCES}

1. Helsinki Process. Proceedings of the Ministerial Conferences and Expert Meetings. Liaison Office of the Ministerial Conference on the Protection of Forests in Europe. FIN-00171, Helsinki, Finland; 1994.

2. Montreal Process. Criteria and Indicators for the Conservation and Sustainable Management of Temperate and Boreal Forests. Fo42-238/1995E. Canadian Forest Service. Natural Resources Canada, Hull, Quebec, Canada; 1995.

3. Bates B, Kundzewicz ZW, Wu S, Palutikof J. Climate Change and Water 2008. IPCC Technical Paper VI, Intergovernmental Panel on Climate Change. Geneva, Switzerland: IPCC Secretariat; 2008.

4. Pyne SJ. Fire: A brief History. Seattle, WA: University of Washington Press; 2001, 204.

5. Ericksson HM, Hall JP, Helynen S. Rationale for forest energy production. In: Richardson J, Bjorheden R, Hakkila P, Lowe AT, Smith CT, eds. Bioenergy from Sustainable Forestry: Guiding Principles and Practice. Dordrecht, The Netherlands: Kluwer; 2002 1-17, Ch. 1.

6. Hakkila P, Parikka M. Fuel resources from the forest. In: Richardson J, Bjorheden R, Hakkila P, Lowe AT, Smith CT, eds. Bioenergy from Sustainable Forestry: Guiding Principles and Practice. Dordrecht, The Netherlands: Kluwer; 2002 19-48, Ch. 2.
7. Andreassian V. Water and forests: from historical controversy to scientific debate. J Hydrol 2004, 291:127.

8. Bell MA, Beckett JM, Hubabrd WF. Impact of harvesting on forest environments and resources. Ottawa, Canada, Canadian Forest Service, Environ Canada 1974, 39.

9. Binkley D, Brown T. Forest practices as nonpoint sources of pollution in North America. Water Resour Bull 1993, 29:729-740.

10. Bosch JM, Hewlett JD. A review of catchment experiments to determine the effect of vegetation changes on water yield and evapotranspiration. J Hydrol 1982, 55:3-23.

11. Brown AE, Zhang L, McMahon TA, Western AW, Vertessey RA. A review of paired catchment studies for determining changes in water yield resulting from alterations in vegetation. J Hydrol 2005, 310:2861.

12. Brown HE, Baker MB Jr., Rogers JJ, Clary WC, Kovner JL, Larson FR, Avery CC, Campbell RE. Opportunities for increasing water yields and other multiple use values on ponderosa pine forest lands. USDA Forest Service, Research Paper RM-129, Fort Collins, CO: Rocky Mountain Forest and Range Experiment Station; 1974, 40. 
13. Stone E. The impact of timber harvest on soils and water. In: Report of the President's Advisory Panel on Timber and the Environment. Washington, DC: U.S. Government printing Office; 1973, 427-467.

14. Neary DG, Hornbeck JW. Impacts of harvesting practices on off-site environmental quality. In: Dyck WJ, Cole DW, Comerford NB, eds. International Energy Agency Project A6 Book, Impacts of Harvesting on Long-Term Site Productivity. London: Chapman and Hall; 1994, 368, Ch. 4.

15. Neary DG. Environmental sustainability of forest energy production. In: Richardson J, Smith T, Hakkila P, eds. Bioenergy from Sustainable Forestry: Guiding Principles and Practices. Amsterdam: Elsevier; 2002. 344, Ch. 6.

16. Neary DG. Changing perceptions of watershed management from a retrospective viewpoint. In Ffolliott PF, Baker MB Jr., Edminster CB, Dillon MC, Mora KL. tech. cords. Land Stewardship in the 21st Century: The Contributions of Watershed Management. USDA Forest Service, Rocky Mountain Research Station, Proceedings RMRS-P-13: Fort Collins, CO; 2000 167-176.

17. Illich I. Water and the Waters of Forgetfulness. London: Boyars Press; 1985.

18. Tainter JA. The Collapse of Complex Societies. New York: Cambridge University Press; 1988, 250.

19. Chandra S. Hydrology in Ancient India. Rookee, India: National Institute of Hydrology; 1990, 106.

20. Kittredge J. Forest Influences. New York: McGraw Hill Book Company; 1948, 394.

21. Ryan DF, Glasser, SP. Goals of this report. In: Dissmeyer GE, ed. Drinking water from forests and grasslands: a synthesis of the scientific literature. General Technical Report SRS-39. Asheville, NC: Southern Research Station; 2000, 246, Ch. 1.

22. Hewlett JD, Hibbert AR. Increases in water yield after several types of forest cutting. Int Assoc Sci Hydrol 1961, 6:5-17.

23. Hornbeck JW, Adams M, Corbett ES, Verry ES, Lynch JA. Long-term impacts of forest treatments on water yield: a summary for northeastern USA. J Hydrol 1993, 150:2043-2052.

24. Zhang L, Dawes WR, Walker GR. Response of mean annual evapotranspiration to vegetation changes at catchment scale. Water Resour Res 2001, 37:701708.

25. Ice GG, Neary DG, Adams PW. Effects of wildfire on soils and watershed processes. J Forest 2004, 102:1620.

26. DeBano LF, Neary DG, Ffolliott PF. Fire's Effects on Ecosystems. New York: John Wiley \& Sons; 1998, 333.

27. Neary DG, Ryan KC, DeBano LF, EDS. Fire effects on soil and water. USDA Forest Service, General Techni- cal Report RMRS-GTR-42, Vol. 4. Fort Collins, CO: Rocky Mountain Research Station; 2005, 250.

28. Wade A, White I, Worthy M, Gill AM, Muellet N, Wasson RJ. Natural and human induced fire impacts on water quality in water supply catchments. In: Lambert M, Daniell TM, Leonard M, eds. Proceedings of Water Down Under 2008. Modbury, SA: Engineers Australia, Casual Productions; 2008, 1201-1212.

29. ACTEW. 2011. Water networks. Available at: http://www.actewagl.com.au/water/networks/default .aspx. (Accessed April 20, 2011).

30. Graham RT, ed. Interim Hayman fire case study analysis. USDA Forest Service, General Technical Report, RMRS-GTR-115. Fort Collins, CO: Rocky Mountain Research Station; 2003, 281.

31. Dissmeyer GE. ed. Drinking water from forests and grasslands: a synthesis of the scientific literature. USDA Forest Service, General Technical Report SRS39. Asheville, NC; Southern Research Station; 2000, 246.

32. Brooks KN, Ffolliott PF, Gregerson HM, DeBano LF. Hydrology and the management of watersheds. Iowa State University Press, Ames, IA, 2003, 502.

33. Ackerman WC, Colman, EA, Ogrosky, HO. Where we get our water. In: The Yearbook of Agriculture. Washington, DC: U.S. Department of Agriculture; 1955, 41.

34. Swanson FJ, Scatena FN, Dissmeyer GE, Fenn ME, Verry ES, Lynch JA. Watershed processes-fluxes of water, dissolved constituents, and sediment. In: Dissmeyer GE, ed. Drinking Water from Forests and Grasslands: a Synthesis of the Scientific Literature. USDA Forest Service General Technical Report SRS39. Asheville, NC: Southern Research Station; 2000. 246.

35. Clary WP, Baker MB Jr., O’Connell PF, Johnsen TN Jr., Campbell RE. Effects of pinyon-juniper removal on natural resource products and uses in Arizona. USDA Forest Service, Research Paper RM-128. Fort Collins, CO: Rocky Mountain Forest and Range Experiment Station; 1974. 28.

36. Velbel MA. Weathering and soil-forming processes. In: Swank WT, Crossley DA, eds. Forest Hydrology and Ecology at Coweeta. New York: Springer-Verlag; 1988, 469.

37. Neary DG, Ice GG, Jackson CR. Linkages between forest soils and water quantity and quality. Forest Ecol Manag 2009, 258:2269-2281.

38. Neary DG. Impacts of wildfire severity on hydraulic conductivity in forest, woodland, and grassland soils. In: Elango L, ed. Hydraulic Conductivity - Issues, Determination and Application. Rijeka, Croatia: INTECH; 2011, 123-142. ISBN 978-953-307-288-3, $434 \mathrm{p}$.

39. Watson FGR, Vertessy RA, Grayson RB. Large-scale modelling of forest hydrological processes and their 
long-term effect on water yield. Hydrol Process 1999, 13: 689-700.

40. Stednick JD. Monitoring the effects of timber harvest on annual water yield. J Hydrol 2000, 176:79-95.

41. Harr RD. Effects of timber harvest on streamflow in the rain-dominated portion of the Pacific Northwest. In: Proceedings of the Workshop on Scheduling Timber harvest for Hydrological Concerns. Portland, OR; 1979, 45.

42. Scott DF, Lesch W. Streamflow responses to afforestation with Eucalyptus grandis and Pinus patula and to felling in the Mokobulaan experimental catchments. I Hydrol 1997, 199:360-377.

43. Kuczera G. Prediction of water yield reductions following a bushfire in ash-mixed species eucalypt forest. J Hydrol 1987, 94:215-236.

44. Bren LJ, Papworth M. Water yield effects of conversion of slopes of a eucalypt forest catchment to radiata pine plantation. Water Resour Res 1991, 27: 24212428.

45. Swank WT, Vose JM, Elliott KJ. Long-term hydrologic and water quality responses following commercial clearcutting of mixed hardwoods on a southern Appalachian catchment. Forest Ecol Manag 2001, 143:63-178.

46. Beschta RL, Pyles MR, Skaugset AE, Surfleet CG. Peakflow responses to forest practices in the western Cascades of Oregon. J Hydrol 2000, 233:102-120.

47. Ingwerson JB. Fog drip, water yield, and timber harvesting in the Bull Run municipal watershed, Oregon Water Resour Bull 1985, 21:469-473.

48. McGuiness JL, Harrold L. Reforestation influences on small watershed streamflow. Water Resour Res 1971, 7: 845-852.

49. Rothacher J. Increases in water yield following clearcut logging in the Pacific Northwest. Water Resour Res 1970, 6:653-658.

50. Pierce RS, Hornbeck JW, Likens GE, Bormann FH. Effect of elimination of vegetation on stream water qual- ity and quantity. Int Assoc Hydrol Sci 1970, 96:311328.

51. Verry ES. Effect of aspen clearcutting on water yield and quality in northern Minnesota. In: Csallany SC, McLaughlin TG, Striffler WD, eds. Watersheds in Transition. Proceedings of a Symposium. Fort Collins, CO: American Water Resources Association and Colorado State University; 1972, 405.

52. Kochenderfer JN, Edwards PJ, Wood F. Hydrologic impacts of logging an Appalachian watershed using West Virginia's Best Management Practices. North J Appl Forest 1997, 14:207-218.

53. Aber JD, Nadelhoffer KJ, Steudler P, Melillo JM. Nitrogen saturation in northern forest ecosystems. Bioscience 1989, 39:378-386.

54. Stednick JD. Timber management. In: Dissmeyer GE, ed. Drinking Water from Forests and Grasslands: A Synthesis of the Scientific Literature. General Technical Report SRS-39. Asheville, NC: Southern Research Station; 2000. 246, Ch. 10.

55. Neary DG, Smethurst PJ, Baillie B, Petrone KC, Cotching $\mathrm{W}$, Baillie CC. Does tree harvesting in riparian areas adversely affect stream turbidity-preliminary observations from an Australian case study. J Soils Sediments 2010, 10:652-670.

56. Beasley RS, Granillo AB. Sediment and water yields from managed forests on flat coastal plain sites. Water Resour Bull 1988, 24:361-366.

57. O'Loughlin CL, Pearce AJ. Influence of Cenozoic geology on mass movement and sediment yield response to forest removal. Bull Int Assoc Eng Geol 1976, 14:4146.

58. Swank WT. Stream chemistry responses to disturbance. In: Swank WT, Crossley DA, eds. Forest Hydrology and Ecology at Coweeta. New York: Springer-Verlag; 1988, 339-357, Ch. 25.

59. Swift LW Jr. Forest access roads: design, maintenance, and soil loss. In: Swank WT, Crossley DA, eds. Forest Hydrology and Ecology at Coweeta. Springer-Verlag, New York, 1988. 469, Ch. 23.

\section{FURTHER READING}

Buol SA, Southard RJ, Graham RJ, McDaniel PA. Soil Genesis and Classification. Ames, IA: Iowa State University Press; 2003. 460 .

Collier KJ, Rutherford JC, Quinn JM, Davies-Colley RJ. Forecasting rehabilitation outcomes for degraded New Zealand pastoral streams. Water Sci Technol 2001, 43:175-184.

O'Loughlin CL, Rowe LK, Pearce AJ. Sediment yield and water quality responses to clearfelling of evergreen mixed forests in western New Zealand. In: Proceedings of the Helsinki Symposium on the Influence of Man on the Hydrological Regime with Special Reference to Representative and Experimental Basins. Wallingford, Oxfordshire: International Association of Hydrological Sciences, PIAHS-AISH Publication No. 130; 1980.

Swanson RH, Golding DL, Rothwell RL, Bernier PY. Hydrologic effects of clear-cutting at Marmot Creek and Streeter watersheds, Alberta. In: Information Report NOR-X-278. Northern Forestry Centre, Canadian Forestry Service, Edmonton, Canada: Northern Forestry Centre, Canadian Forestry Service; 1986, 27. 